\title{
COMPARISON OF THE BALTIC STATES' TAX REDUCTION POLICY FOR DONATIONS TO UNIVERSITIES
}

Laila Kundzina ${ }^{1}$, Mg. hist.; Baiba Rivza², Prof. Dr. oec.

\begin{abstract}
The oldest Universities of the Baltic states: Vilnius University, Tartu University and University of Latvia are financed by governments. Finances are short for all universities' development plans and they are looking for donations from private patrons and entrepreneurs. Tax reduction substantially motivates philanthropists to donate to university development projects. Aim of this research is to compare the legal framework for attracting donations to universities of the Baltic States. In each of the Baltic States there is a different tax reduction policy, but in all countries are the same strands stated by state for stimulating receive tax reductions if philanthropists are willing to donate to universities. Tax reductions and their application principles to donors in the Baltic States provide a sound opportunity to donate to universities.
\end{abstract}

Key words: philanthropy, university, Baltic States, tax reduction policy, public benefit. JEL code: M30

\section{Introduction}

Universities are increasingly looking for donations from private persons and entrepreneurs to supplement the public funding to contribute to various scholarships and research projects. This indicates that, in case of universities, the costs are proportionally higher than the revenue (Sato M., 2005). At present, universities can benefit from unprecedented opportunities (Orlikov J., 2006), receiving funding from the state and various European grants, which must be augmented by additional funding from philanthropists, both individuals and enterprises, to compete in the global market and simultaneously prove their competitiveness at the national level. To attain these aims, it is necessary to reduce costs while increasing productivity and finding alternative sources of revenue (Bloland H., 2002). This situation means that universities are compelled to invest more intense effort in seeking diverse sources of funding, including philanthropists' donations for university projects, scholarships. Throughout the world, the importance of donation to universities is considered a very important factor to ensure full development of universities (Barr N., 1993; Johnstone D., 2016; Chung-Hoon T., 2005; Fransen F., 2007; Jacobs L., 2007; White F., 2011). Tax reduction substantially motivate donation (Isa, R. 2014).

The authors' research is aimed at comparing the legal framework for attracting donations to universities of the Baltic States. The hypothesis - tax deductions and their application principles to philanthropists in the Baltic States provide a sound opportunity to donate to universities.

The research employs qualitative research: the logical constructive method, the monographic method, the method of analysis and synthesis. The research is based on scientific theoretical literature, scientific articles and the legal framework analysis of the Republic of Latvia, the Republic of Lithuania and the Republic of Estonia.

\section{Research results and discussion \\ 1. The legal framework for philanthropists and donation recipients in the Republic of Latvia}

The tax reduction policy in the Republic of Latvia is defined by a number of regulatory documents. Associations and foundations need to register for the public benefit status granted by the Republic of Latvia Ministry of Finance to be able to provide tax incentives to their donors. The operation of public benefit organizations is governed by the Public Benefit Organization Law determining which organizations are to be considered public benefit, how do they obtain and lose that status, how donations can be received and used, as well as restrictions on the activities of these organizations and the use of donations. The law also determines the tax deductions that can be granted to natural 
and legal persons who donate to a public benefit organization (Public Benefit Organization Law, 2004).

Public benefit organization status may be granted to an association, foundation or religious organization. The procedure of granting the status is maintained by the Public Benefit Commission. It consists of an equal number of authorized officials, as well as representatives of associations and foundations, and works under the auspices of State Revenue Service. It provides a justified opinion on the conformity of the applying association, foundation or religious organisation to the essentials of public benefit organisation activities, as well as the conformity of the use of property and financial means thereof to the provisions of the Public Benefit Organization Law. If such an opinion is received, the organization must additionally meet the following criteria: the purpose stated in the statutes, constitution or statutes of the association, foundation or religious organization is the activity of the public good, and the association, foundation or religious organization carries out the activity of public good; the association, foundation or religious organization has No tax debts (Law on Public Benefit Organizations, 2004). The non-governmental organisation that has received the status of the public benefit organization can attract donors - legal entities entitled to tax relief provided for in Section 12 of the Enterprise Income Tax Law - residents and permanent representations can receive a tax reduction in three different ways.

The law stipulates a tax relief to donors applicable to the taxpayer donating to a public benefit organisation. The taxpayer is entitled to choose one of the following relief possibilities:

1) Not to include the donated amount in the base taxable with the enterprise income tax in the taxation period but not more than $5 \%$ of the profits from the previous reporting year after the calculated taxes (Enterprise Income Tax Law, 2017);

If, for example, in 2017, the profit for the previous reporting year is 10000 euro, then the company is exempt from paying the enterprise income tax, if this company donates up to 500 euros (that is, $5 \%$ ) to a public benefit organisation.

$10000 \times 5 \%=500$ euro as the maximum in this case.

However, if the company donates over 500 euro, it has to pay an extra $25 \%$. For example, if 500 euros are donated and there is another donation of 500 euro, then that company donates those additional 500 euro and still has to pay $25 \%$ enterprise income tax, which for the donating company means parting with 500 euro plus 125 euro.

2) Not to include the donated amount in the base taxable with the enterprise income tax in the taxation period but not more than $2 \%$ of the total gross work remuneration calculated for employees in the previous reporting year from which State social insurance contributions have been made (Enterprise Income Tax Law, 2017);

If in 2017 the total gross salary of the employees was 10000 euro, then $2 \%$ is the donation ceiling.

$10000 \times 2 \%=200$ euro as the maximum in this case.

However, if the donor donates more than 200 euros, for example, another 200 euros, the donor pays enterprise income tax $25 \%$ of the additionally donated amount, which in this case means paying additional 50 euro.

3) Since 2019, the following option is also in force: to reduce the enterprise income tax calculated on the dividends for the reporting year in the taxation period by $75 \%$ of the donated amount but not exceeding $20 \%$ of the calculated amount of enterprise income tax calculated on the dividends. 
Choosing the third option, the donation amount does not reduce the taxable base, but instead reduces the enterprise income tax from dividends.

Private persons who have the right to use the tax relief specified in the Personal Income Tax Law the relief on the taxable income of a natural person may not exceed $20 \%$ of the taxable income (Personal Income Tax Law, 1993).

\section{The legal framework for philanthropists and donation recipients in the Republic of Estonia}

In the Republic of Estonia, for philanthropists to receive tax relief, the non-profit organization, foundation or religious organization, to whom the philanthropists aspire to donate, must be included into the list of non-profit associations, foundations and religious associations benefiting from income tax incentives approved by the government after obtaining a recommendation from expert committee. Then the philanthropist payable income tax can be reduced by the amount that equals the donated sum (Income Tax Act, 2000). New organizations are included in the list twice a year, and the list is confirmed by the government. The same status applies to donations made to church and parish registers (Income Tax Act, 2000). Organizations also have a duty to report to the Estonian Tax and Customs Board about their philanthropists, while the donors must fill out a tax declaration form. If any of these actions are not carried out, the donor will not receive tax deduction. Overall, a philanthropist, who is a private individual, can receive up to $5 \%$ of the same year's income from which other deductions have already been made (interest, education costs etc.). The Tax and Customs Board may request documentary evidence of the donation (Income Tax Act, 2000).

Companies - philanthropists also receive tax relief, if the total donated amount does not exceed $10 \%$ of the previous year's profit, or $3 \%$ of the current year's social tax amount, i.e., $3 \%$ of the sum of paid salaries and benefits (Income Tax Act, 2000). Tax reliefs are also applied to nonresidents, whether corporate or private (Income Tax Act, 2000).

\section{The legal framework for philanthropists and donation recipients in the Republic of Lithuania}

In the Republic of Lithuania, donation is governed by the Law on Charity and Sponsorship Funds of the Republic of Lithuania, 2000. This law combines the definitions of chariTable organizations and defines who can be a philanthropist and a recipient, as well as stipulates the legal framework for charity and sponsorship. Currently, both charity and sponsorship funds are entitled to establishing enterprises to carry out economic activities by that are not prohibited by law, do not run counter to the organisation's goals and are necessary to achieve the organisation's goals.

The purpose of the law is to determine in which cases the tax deductions and relief from import duties are applicable. The law distinguishes between the concepts of charity and sponsorship.

Charity is an activity aimed at:

1) assistance and free provision of services to persons to whom that is essential: physically restricted, sick or lonely people unable to work, orphans and children deprived of parental care, large families or families with insufficient resources, unemployed, as well as the people whose income fails to meet their minimal socially accepTable needs;

2) assistance to charity organizations and Caritas (Lithuanian Women's Association) organizations, as well as foundations and religious centres that implement charity and sponsor the individuals listed in Article 2 (1) (1), as well as Lithuanian communities abroad;

3) persons recognised as victims of war, natural disasters, fires, ecological catastrophes, epidemics, and outbreaks of contagious diseases, and assistance in relief of such catastrophes and epidemics; 
4) assistance in finding employment by creating jobs or retraining socially excluded people who have lost their jobs.

On the other hand, sponsorship is aimed at:

1) promoting development of science, culture, education, art, religion, sport, health care or social care, and support programmes thereof;

2) to promote environmental protection and environmental planning programmes;

3) to support work programmes aimed at the protection of historical, natural, architectural, cultural and artistic monuments; and

4) to promote other programmes of social interest initiated by the Government of the Republic of Lithuania (Law on Charity and Sponsorship Funds of the Republic of Lithuania, 2012).

The funds of chariTable organizations and foundations are completely exempt from income tax irrespective of the amount. However, if they generate income from economic activity and their income exceeds 300000 euro per annum, the income tax of $15 \%$ is applied to all the income brought by economic activity. For philanthropists, the portion of the donation that exceeds $20 \%$ of taxable income is taxed according to the normal procedure. Unfortunately, this applies only to donors - legal entities. In the earlier version of the law, the philanthropists - private individuals were able to receive a reduction from income tax, reducing the taxable base amount by $15 \%$. In the later amendments to the law, this deduction disappeared, leaving only the deduction from income tax of legal entities (Jatautaite E., Vaidelyte E., 2015). For legal entities, the tax relief can reach even $40 \%$ when donating to organizations with a charity recipient status. These can include not only chariTable foundations but also schools, museums, libraries, etc. There is also a model, where an organization donates a certain percentage of its income to a chariTable organization or to an organization with a charity recipient status. This percentage may not exceed $2 \%$ (Jatautaite E., Vaidelyte E., 2015).

The Republic of Lithuania Law on Charity and Sponsorship Funds also provides for a special regulatory framework for the formation and management of endowment fund, which must also be laid down in the organisation's (i.e., Fund's) statutes, in accordance with the stipulations of the Law on Charity and Sponsorship Funds. The amount of the endowment fund may increase from the Fund's own resources, following the decision issued by the general meeting of the Fund's shareholders on the principles of investment policy for the next period, but not exceeding $50 \%$, or from the additional sums donated to endowment fund. Endowment fund may also decrease, but it must be restored over a period of three financial years from the date when the first decrease is registered. If the endowment capital is not restored within the period of three years, or has fallen by more than $30 \%$ of the average endowment fund capital registered over three years, the law requires the Fund to terminate the management of endowment fund (Law on Charity and Sponsorship Funds of the Republic of Lithuania, 2012).

Lithuania's percentage system works quite similarly to other countries. Lithuanian citizens and non-residents of Lithuania may choose to divert up to $2 \%$ of their paid personal income tax to the chosen public benefit structure. It is possible to divide $2 \%$ in portions, provided the set amount is not below 2.9 euro. From July to mid-November of each calendar year, the tax inspectorate transfers the specified amounts to the recipients, whom the private philanthropists have indicated in their income declarations. The Lithuanian State Tax Inspectorate also publishes $2 \%$ of the results for the year (Law on Charity and Sponsorship Funds of the Republic of Lithuania, 2012). 
State-defined support strands for receiving tax reduction

\begin{tabular}{|l|c|c|c|}
\hline \multicolumn{1}{|c|}{ Purpose of donation } & Latvia & Lithuania & Estonia \\
\hline Charity & $\mathrm{X}$ & $\mathrm{X}$ & $\mathrm{X}$ \\
\hline Defence of human rights and individuals' rights & $\mathrm{X}$ & $\mathrm{X}$ & $\mathrm{X}$ \\
\hline Promotion of civil society development & $\mathrm{X}$ & $\mathrm{X}$ & $\mathrm{X}$ \\
\hline Promotion of science & $\mathrm{X}$ & $\mathrm{X}$ & $\mathrm{X}$ \\
\hline Promotion of education & $\mathrm{X}$ & $\mathrm{X}$ & $\mathrm{X}$ \\
\hline Promotion of culture & $\mathrm{X}$ & $\mathrm{X}$ & $\mathrm{X}$ \\
\hline Promotion of health & $\mathrm{X}$ & $\mathrm{X}$ & $\mathrm{X}$ \\
\hline Support to disease prevention & $\mathrm{X}$ & $\mathrm{X}$ & $\mathrm{X}$ \\
\hline Support and promotion of sport & $\mathrm{X}$ & $\mathrm{X}$ & $\mathrm{X}$ \\
\hline Environmental protection & $\mathrm{X}$ & $\mathrm{X}$ & $\mathrm{X}$ \\
\hline Assistance in catastrophes and emergency situations & $\mathrm{X}$ & $\mathrm{X}$ & $\mathrm{X}$ \\
\hline $\begin{array}{l}\text { Raising of social welfare of society, especially the } \\
\text { poor and socially disadvantaged groups }\end{array}$ & $\mathrm{X}$ & $\mathrm{X}$ & $\mathrm{X}$ \\
\hline Support to religious organisations & $\mathrm{X}$ & $\mathrm{X}$ & $\mathrm{X}$ \\
\hline Support to political organisations & & & \\
\hline Support to enterprises & & & \\
\hline Support to trade unions & & $\mathrm{X}$ & $\mathrm{X}$ \\
\hline
\end{tabular}

Source: author's analysis based on documents' studies

Tax reduction applicants

\begin{tabular}{|l|c|c|c|}
\hline \multicolumn{1}{|c|}{ Types of philanthropists } & Latvia & Lithuania & Estonia \\
\hline Private individuals, residents & $\mathrm{X}$ & $\mathrm{X}$ & $\mathrm{X}$ \\
\hline Private individuals, non-residents & & $\mathrm{X}$ & $\mathrm{X}$ \\
\hline Companies, residents & $\mathrm{X}$ & $\mathrm{X}$ & $\mathrm{X}$ \\
\hline Companies, non-residents & & $\mathrm{X}$ & $\mathrm{X}$ \\
\hline
\end{tabular}

Source: author's analysis based on documents' studies

State-defined support strands for receiving tax reduction for all the Baltic States generally are the same, the same are exceptions: do not support donations for political parties and enterprise organizations. Regarding the types of philanthropists who can receive tax reductions, only in Latvia non-residents cannot receive tax reductions.

\section{Conclusions, proposals, recommendations}

1) In defining the criteria for acquiring the status of a public benefit organization, the state indicates the purposes whose attainment it considers to be in public interest. Donation to such organizations permit to obtain tax relief, thus indicating that the state accepts the purposes for which these donations are being diverted. It does not only relieve the state of the required expenditure, but also promote the involvement of the wider society in solving topical problems. It might seem that legislation for non-governmental organizations should be as liberal as possible, so that engagement in civic activities is simple and, as a minimum, would not cause problems and losses.

2 ) On the other hand, the role of the state is to prevent abuse of the non-profit organization and public benefit organization status. The aim of the regulations is to ensure that private funds are to the highest possible level channelled to the purposes beneficial to the state and society.

3) In case of Latvia, tax reduction can only be obtained for donations to public benefit organizations, whereas tax relief is not granted for donation to organizations that have the same goals but have not obtained this status, nor for giving to organizations that work in several directions, including 
those that might qualify as public benefit activities. Thus, in Latvia it is not possible to grant tax reduction for donations to specific projects, if they are not carried out by public benefit organizations. Such regulation to a certain extent limits the possibilities for donation, as well as the opportunities to implement public benefit projects, if aspired to by organizations whose main activity does not fall within the definition of public benefit.

4) The legal framework of the Republic of Latvia provides for tax reduction to philanthropists who are residents of Latvia: companies and private persons. Businesses and individuals who are nonresidents of the Republic of Latvia in case of donation are not subject to tax relief. The new legal framework for philanthropists - companies - has been recently changed, despite the heated public protests of the associations and foundations. Prospectively, a study would be needed exploring the ways how the new legal framework has changed the culture of donation from the perspective of companies.

5) The legal framework of the Republic of Estonia provides for more extensive possibilities for philanthropists' groups to receive tax relief, donations can be made by both residents and nonresidents. On the other hand, there are only two options for applying tax rebates.

6) The legal framework of the Republic of Lithuania provides extensive opportunities for philanthropists to receive tax relief. However, the recipients of donations have to wait over half a year until they receive donations for the previous period. Lithuanian charity and sponsorship funds can engage in economic activities and receive tax reductions on the respective taxes. It is an additional incentive for organizations to develop and increase their charity activities based on additional income.

7) To sum up, all three Baltic States have a sufficient legal framework, enabling attraction of donations to the universities, ensured by the valid tax incentives and their application principles to philanthropists.

8) The questions arising from the current study: Do universities of the Baltic States have strategies for attracting donations based on the existing legal framework for philanthropists, enabling them to receive tax relief? If such strategies exist, are they updated with the changes of the tax reduction policy?

\section{Acknowledgments}

The preparation of the paper was supported by the National Research Programme 5.2. Project "INTERFRAME-LV".

\section{Bibliography}

1. Barr, N.A. (1993). Alternative Funding Resources for Higher Education. Econ. J. 103, pp. 718-728.

2. Betzler D. U. (2014). Governance and Professionalization in Fundraising Management. Doctoral thesis. Faculty of Economics and Social Sciences of the University of Fribourg, Fribourg, p. 180.

3. Bloland, H.G. (2002). No ILnger emerging, fundraising is a profession. CASE Int. J. Educ. Adv. p. 3, 7-19.

4. Chung-Hoon, T.L.; Hite, J.M.; Hite, S.J. (2005). Searching for enduring donor relationships: Evidence for factors and strategies in a Donor/Organization integration model for fund raising. CASE Int. J. Educ. Adv. p. 6, 34-53.

5. Enterprise Income Tax: The Republic of Latvia law. (2017). Latvijas Vestnesis, No. 156, 08.08.2017, p. 2.

6. Fransen, F.J. (2007). Leveraging philanthropy in Higher Education. Acad. Quest. 2007, p. 20, 150-153.

7. Income Tax Act: The Republic of Estonia law. (2000). Retrieved: https://www.riigiteataja.ee/en/eli/504092017017/consolide. Access: 15.02.2019.

8. Isa R. M. (2014). Growing the University's funding through philanthropy: an Australian and a Malaysian case study. Doctoral thesis. University of Tasmania. p. 128.

9. Jacobs, L. (2007). The kindness of strangers: Philanthropy and Higher Education. CASE Int. J. Educ. Adv. p. 7, 65-67. 
10. Jatautaite, B., Vaidelyte, R. (2017). Lithuania Country Report. ERNOP publication. Retrieved: http://ernop.eu/wp-content/uploads/2017/01/Giving-in-Europe-2013-total-versie-16-01-2017-upload-toERNOP.pdf. Access: 15.02.2019.

11. Johnstone, D.B. (2004). University revenue diversification through philanthropy: International perspectives. Retrieved: http://www.intconfhighered.org/BruceJohnstone.pdf. Access: 15.02.2019.

12. Law on Charity and Sponsorship: The Republic of Lithuania law. (1993). Retrieved: https://eseimas.Irs.It/portal/legalActPrint/lt?jfwid=rivwzvpvg\&documentId=TAIS.21900\&category=TAD. Access: 15.02.2019.

13. Moore D, Hadzi-Miceva, K., Bullain, N. (2008). A Comparative Overview of Public Benefit Status in Europe. International Journal of Not-for-Profit Law, 11(1). Retrieved: http://www.icnl.org/research/journal/vol11iss1/special_1.htm. Access: 15.02.2019.

14. On Personal Income Tax: The Republic of Latvia law. (1993). Latvijas Vestnesis, No. 32, 01.06.1993, p. 6.

15. On Taxes and Duties: The Republic of Latvia law. (1995). Latvijas Vestnesis, No. 26, 01.04.1995, p. 15.

16. Orlikoff, J.E.; Totten, M.K. (2006). Philanthropy and governance. It's déjà vu all over again. Healthc. Exec. p. 22, 54-57.

17. Public Benefit Organisation Law: The Republic of Latvia law. (2004). Latvijas Vēstnesis, No. 106, 07.07.2004, p. 7.

18. Rutzen, D., Moore, D., Durham, M. (2009). The Legal Framework for Not-for-Profit Organizations in Central and Eastern Europe. The International Journal of Not-for-Profit Law, 11(2), International Center for Not-forProfit Law. Retrieved: http://www.icnl.org/research/resources/regional/CEE \%200verview_eng.pdf. Access: 15.02.2019.

19.Sato, M. Education, (2005). Ethnicity and Economics: Higher Education Reforms in Malaysia 1957-2003. Nagoya Univ. Commer. Bus. Adm. p. 1, 73-88.

20. White, F.L. (2011). Creating effective Board-CEO relationships and fundraising to achieve successful student outcomes. New Dir. Community Coll. p. 156, 23-29. 